\title{
THE NOMENCLATURE OF RACHICENTRON OR ELACATE, A GENUS OF ACANTHOPTERYGIAN FISHES.
}

\author{
By Theodore Gill, LL. D.
}

The Universally accepted name Elacate must unfortunately be supplanted by one entirely unknown to fame, overlooked by all naturalists, and found in no nomenclator. A brief history of the nomenclature of the genus is timely.

In 1814 Dr. Mitchill, of New York, first described, as a new generic type, a fish which he called Centronotus spinosus. He specifically designated the genus as "new" and distinguished it by the broad head, distant eyes, prominent lower jaw, and eight dorsal spines, besides other less important characters. It was apparently merely through a coincidence and natural fitness that he gave the same name as Lacépède had previously used for a heterogeneous genus, including the same species as well as the pilot-fish. Nevertheless, the previous use of the name by both Schneider (1801) and Lacépède (1802), precludes the use for the genus of Mitchill.

In 1826 Dr. Kaup treated of the same fish and gave to it the name Rachycentron typus. He gave a good diagnosis, erring only in attributing seven rays to the ventral fins. The rollowing abstract will prove this claim:

\section{RACHYCENTRON. GASTEROSTEUS, Linnæus.}

"Kennz. der Gattung. Zähne fein und borstenförmig; Kopf plattgedruickt; 7 Kiemenstrahlen. Brustflossen klein; Bauchflossen 7 strahlig. Erste Rückenflosse enthält freye von einander enfernte Stacheln. Zweyte Rückenflosse und die Afterflosse lang, vom Schwanze unterschieden. Schuppen fein."

Diese Gattung hat sehr viel ähnliches mit Echeneis und hat nur die freyen Stacheln mit C'entronotus gemein, die sich durch den zusammengedrückten Körper sehr von dieser untersheidet. Eine Art Rachycentron typus.

The identity of the fish with the Gasterosteus canadus of Linnæus, the "Motta" of Russel and the "Ceixupira" of Marcgrave, was recognized.

In 1827 Kaup amended the name into Rachicentron and expressed his views as to the affinities of the genus in the following terms:

Wegen des plattgedriickten Kopfes, \&c., habe ich diese Art, welche fast in allen Meeren verkommt, zu einer eigenen Gattung erhoben, welche am nächsten mit Tetragonurus verwandt ist.

Proceedings of the United States National Museum, Vol. XVIII-No. 1059. 
Kaup now further identified the Scomber niger of Bloch, Centronotus gardenii of Lacépède, and Centronotus spinosus of Mitchill with his species.

In 1829 Cuvier first proposed the generic name with the French plural form "les Elacates" for the same genus, basing on the "Pedda mottah" the species "El. motta," and for the Centronotus spinosus substituting the new name "El. americana." The "Ceixupira" or Scomber niger was retained in the same genus with the pilot-fish, as in the first edition, although those names are mere synonyms of the typical Elacate, as had been recognized in 1827 by Kaup.

In view of these facts, it will be obvious that adherence to the rules of priority compels us to take up Kaup's name for the genus in question, and for the family name, if the including group RACHICENTRID AE should be employed. Those who adhere strictly to rules of priority and will retain all errors and slips because they were in the earliest names, will prefer Rachycentridæ and Rachycentron, although the latter was merely a slip in Kaup's original memoir and was speedily corrected. I prefer to regard it as a typographical error and to take the later and correct form.

The history of the nomenclature is epitomized in the following synonymy :

\section{Genus RACHICENTRON.}

=Centronotus, Mitchill, Trans. Lit. Phil. Soc. N. Y., I, p. 490, 1814.

=Rachycentron, KAUP, Isis, XIX, col. 89, 1826.

=Rachicentron, KAUP, Isis, XX, col. 624, 1827.

=Les Elacates, Cuvier, Règne Animal, 2. ed., ${ }^{1}$ II, p. 203, 1829.

=Elacate, Cuvier and Valenciennes, Hist. Nat. Poiss., VIII, p. 328, 1831.

=Elacate, Swainson, Nat. Hist. Fishes, etc., II, pp. 176, 243, 1839.

<Meladerma, Swanson, Nat. Hist. Fishes, etc., II, pp. 176, 243, 1839 . (Type

"M. nigerrima" = "Pedda mottah.")

Gasterosteus, sp., Lixneus et al.

Centronotus, sp., LACÉPìdE.

The only now recognizable species rejoices in a very large number of names, as the following synonymy will show. This synonymy expresses the general belief of all recent ichthyologists. Nevertheless, it may well be that two or more species have been confounded, and at least a renewed critical and comparative examination of sufficient material is very desirable.

\section{RACHICENTRON CANADUM.}

Gasterosteus canadus, Linveus, Syst. Nat., ed. 12, I, p. 491, 1766.

Scomber niger, BLoch, Ichthyologie, X, p. 48, pl. CCCXXXvir, 1797.

Centronotus gardenii, LAcépìne, Hist. Nat. Poiss., III, pp. 310, 318, 1802.

[Centronotus] niger, Cuvier, Règne Animal, II, p. 320, 1817.

Centronotus spinosus, Mitchild, Trans. Lit. Phil. Soc. N. Y., I, p. 490, pl. 3, fig. 9,1815 .

${ }^{1}$ Les Centronotus (Centronotus) sp., Cuvier, Règne Animal, II, p. 321, 1817. 
Rachycentron typus, KAUP, Isis, XIX, col. 89, 1826.

Rachicentron typus, KAUP, Isis, col. 624, 1827.

[Naucrates] niger, Cuvier, Règne Animal, 2. ed., II, p. 203, 1829.

El[acate] motta, Cuvier, Règne Animal, 2. ed., II, p. 203, 1829.

El[acate] americana, CuviEr, Règne Animal, 2. ed., II, p. 203, 1829.

Elacate pondiceriana, Cuvier and Valenciennes, Hist. Nat. Poiss., VIII, p. 329, 1831.

Elacate motta, Cuvier and Valenciennes, Hist. Nat. Poiss., VIII, p. 332, pl. CCXXXir, 1831.

Elacate malabarica, Cuvier and Valenciennes, Hist. Nat. Poiss., VIII, p. 332, 1831.

Elacate atlantica, Cuvier and Valenciennes, Hist. Nat. Poiss., VIII, p. 334, pl. CCXXXIII, 1831.

Elabate bivittata, Cuvier and VAlenciennes, Hist. Nat. Poiss., VIII, p. 338, 1831. Elacate atlantica, Swansson, Nat. Hist. and Class. Fishes, II, p. 243, 1839.

Meladerma nigerrima, Swanson, Nat. His. and Class. Fishes, II, p. 243, 1839.

Nancrates niger, Swanson, Nat. Hist. and Class. Fishes, II, p. 245, 1839.

Elacate canada, Dекау, N. Y. Fauna, Fishes, p. 113, pl. xxv, fig. 77, 1842.

Elacate falcipinnis, Gosse, Nat. Soj. Jamaica, p. 208, 1851.

Elacate nigra, Günther, Cat. Fish. Brit. Mus., II, p. 375, 1860. 


\section{$2 \mathrm{BHL}$ Biodiversity Heritage Library}

Gill, Theodore. 1896. "The nomenclature of Rachicentron or Elacate, a genus of acanthopterygian fishes." Proceedings of the United States National Museum 18(1059), 217-219. https://doi.org/10.5479/si.00963801.18-1059.217.

View This Item Online: https://www.biodiversitylibrary.org/item/32799

DOI: https://doi.org/10.5479/si.00963801.18-1059.217

Permalink: https://www.biodiversitylibrary.org/partpdf/5705

\section{Holding Institution}

Smithsonian Libraries

\section{Sponsored by}

Smithsonian

\section{Copyright \& Reuse}

Copyright Status: NOT_IN_COPYRIGHT

This document was created from content at the Biodiversity Heritage Library, the world's largest open access digital library for biodiversity literature and archives. Visit BHL at https://www.biodiversitylibrary.org. 